\title{
Soil Amendments Reduce Roof Garden Weight and Influence the Growth Rate of Lantana
}

\section{Nektarios Panayiotis ${ }^{1}$, Tsiotsiopoulou Panayiota ${ }^{2}$, and Chronopoulos Ioannis ${ }^{3}$ \\ Agricultural University of Athens, Department of Floriculture and Landscape Architecture, 75, Iera Odos, 118 55, Athens, Greece}

Additional index words. intensive green roof, vegetative layer, urea-formaldehyde resin foam, peat, perlite

\begin{abstract}
Four substrates were investigated for their efficacy as roof garden vegetative layers. The substrates comprised a sandy loam soil (S), sandy loam soil amended with urea formaldehyde resin foam $(S: F)$ in a proportion of $60-40 \mathrm{v} / \mathrm{v}$, sandy loam soil amended with peat and perlite (S:P:Per) in a proportion of 50-30-20 v/v and peat amended with urea formaldehyde resin foam $(P: F)$ in a proportion of $60-40 \mathrm{v} / \mathrm{v}$. The substrates were evaluated for their physical and chemical properties and their capacity to sustain growth of Lantana camara L. Physical and chemical evaluation included weight determination at saturation and at field capacity, bulk density determination, water retention, air filled porosity at $40 \mathrm{~cm}, \mathrm{pH}$ and EC. When compared to the control (S) a weight reduction of $16.8 \%, 23.9 \%$ and $70.3 \%$ was obtained at field capacity with S:F, S:P:Per and P:F substrates respectively. Bulk density was reduced by $46 \%, 43 \%$ and $95 \%$, in substrates S:F, S:P:Per and P:F, respectively, compared to the control substrate S. Air-filled porosity at $40 \mathrm{~cm}$ was slightly increased for substrate $S: F$ while it was substantially increased for substrate $\mathrm{P}: \mathrm{F}$. The $\mathrm{pH}$ response between the initiation and the termination of the study was similar for the four substrates. EC decreased in substrates $S$ and $S: P$ :Per but increased in substrates S:F and P:F. Plant growth was monitored as shoot length, shoot number, main shoot diameter and the number of buds and flowers. Substrates $S$ and $S: F$ resulted in similar plant growth, while substrate S:F promoted flowering. Substrate S:P:Per induced slow plant growth during the first 6 months which subsequently increased resulting in a final growth that was satisfactory and comparable to the $S$ and $S: F$ substrates. Substrate P:F did not support sufficient plant growth and its use should be considered only in special cases where reduced weight of the roof garden is imperative.
\end{abstract}

Roof gardens have received increased attention in recent years as an urban horticulture alternative (Boivin et al., 2001). The philosophy of a roof garden relies on the fact that the plant material that is destroyed during the construction phase will be restored at the top of the building and will reduce the adverse effects of urbanization and deforestation (Osmundson, 1999).

The contribution of roof gardens to the urban environment is manifold. It has been established that roof gardens reduce temperature and solar irradiance, provide up to $50 \%$ reduction in the heat flux into buildings (Onmura et al., 2001), thus resulting in significant building energy savings. In addition, roof gardens contribute to the Urban Heat Island Effect mitigation (Osmundson, 1999), protect and secure the longevity of the roof structure, grade rainstorm water distribution (Liesecke, 1998; Osmundson, 1999; Schade,

\footnotetext{
Received for publication 23 July 2002. Accepted for publication 31 Dec. 2002. The authors want to thank Harold Passam for his help on reviewing and improving the manuscript and Ekaterini Chronopoulou for the temperature and precipitation data submission.

${ }^{1}$ Lecturer.

${ }^{2}$ Graduate Research Assistant

${ }^{3}$ Professor.
}

2000; Scholz-Barth, 2001), and improve the aesthetic quality of the urban environment.

Despite their numerous advantages, roof gardens cannot yet be considered a common practice. The main obstacles for wide public acceptance is the high initial construction cost and the increased load that is exerted on the frame of the buildings. The last results mainly from the substrate weight (Scrivens, 1990) and constitutes a major dilemma for roof garden construction on aged buildings, especially in areas that exhibit a high frequency of earthquakes.

Roof gardens are distinguished into intensive and extensive types. The distinction between the two types depends on the utilized plant material, the depth and type of the substrate and the frequency of the maintenance requirements. Intensive type roof gardens utilize a substrate with a depth that varies from $0.30 \mathrm{~m}$ to more than $1.25 \mathrm{~m}$. Groundcovers, shrubs and even trees can be planted while maintenance demands concerning irrigation and fertilization are frequent. In contrast, extensive roof gardens utilize substrates with minimal depth $(0.02-0.15 \mathrm{~m})$ and plant material that consists from groundcovers and small herbaceous plants capable of self-propagating and growing without any maintenance.

In extensive roof gardens, the minimal substrate depth in conjunction with the uti- lization of lightweight materials (Fischer and Jauch, 1995) reduces substantially the weight of the construction. However, these lightweight materials are appropriate only for groundcover types of vegetation and, in most cases, stepping on them is not recommended.

In intensive roof gardens with shrubs or trees, soil forms the basic constituent of the substrate, in order to support plant growth, increase water-holding capacity, and provide sufficient anchorage to the plants (FLL, 1995). In an effort to minimize the load on the frame of the buildings, lightweight materials can be incorporated to decrease the weight of the substrate without sacrificing plant growth and anchorage. Apart from traditional lightweight materials such as peat and perlite, resin foams are receiving increasing attention as soil amendments for roof gardens. However, there is a lack of experimental data to evaluate the capacity of these lightweight soil amendments to reduce substrate weight and support plant growth.

Therefore, the goal of the present study is: 1) to investigate the contribution of different lightweight soil amendments on the physical properties and weight reduction of the substrate and 2) to evaluate the capacity of each substrate to support plant growth.

\section{Materials and Methods}

A field study was conducted at the Dept. of Floriculture and Landscape Architecture of the Agricultural Univ. of Athens (lat. 37 $58^{\prime} 55^{\prime \prime} \mathrm{N}$ and long. $\left.23^{\circ} 32^{\prime} 14^{\prime \prime} \mathrm{E}\right)$, Greece, during the years $2000-01$. The study occupied an outdoor area of $150 \mathrm{~m}^{2}$.

Lantana camara L. was selected for the study since it possesses several characteristics that are desirable for vegetation establishment on roof gardens, such as minimal maintenance requirements, endurance to airborne pollutants (Kulshreshtha et al., 1994), capacity to grow under high temperature and irradiance, and prolonged and prolific flowering when growing in temperate climates.

On 9 Oct. 2000, 79-d-old rooted cuttings taken from a single plant of $L$. camara were pinched to a height of $20 \mathrm{~cm}$ and were transplanted to the appropriate substrate after the perlite had been removed from their root system.

Substrate constituents were: 1) a sandy loam soil composed of $78.88 \%$ sand, $8 \%$ silt and $13.12 \%$ clay, an EC of $1.6 \mathrm{dS} \cdot \mathrm{m}^{-1}$ and $\mathrm{pH} 7.25$ 2) a Lithuanian sphagnum peat moss (Novobalt, Lithuania) having an organic matter of $35 \%$ w/w, total N 0.4\% w/w and pH 3.7; 3) Perlite (Isocon S.A., Athens, Greece) with 80-100 $\mathrm{kg} \cdot \mathrm{m}^{-3}$ dry weight, a particle size distribution between 1-5 mm and $\mathrm{pH} 6.7$; and 4) a ureaformaldehyde resin foam(Fytofoam; Fytofoam Hellas Ltd., Athens, Greece) with a dry weight of $18 \mathrm{~kg} \cdot \mathrm{m}^{-3}, 60 \% \mathrm{v} / \mathrm{v}$ water-holding capacity, a slow biodegradation rate of more than 20 years, a $\mathrm{pH}$ of 2.5 and providing small amounts of $\mathrm{N}$ (Bunt, 1988). The urea-formaldehyde resin foam was added as pre-wetted flakes over the whole depth of the profile.

The above materials were used to create the 
following four substrates: 1) $100 \%$ sandy loam soil (S), which served as the control; 2) sandy loam soil amended with the urea-formaldehyde resin foam $(\mathrm{S}: \mathrm{F})$ in a proportion of 60:40 (v/v); 3) sandy loam soil mixed with peat and perlite (S:P:Per) in a proportion of 50:30:20 (v/v); and 4) peat amended with a urea-formaldehyde resin foam (P:F) in a proportion of 60:40 (v/v). The initial $\mathrm{pH}$ of substrate $\mathrm{P}: \mathrm{F}$ was 3.15 , and therefore was corrected to 6.42 with the addition of $22 \mathrm{~g} \cdot \mathrm{L}^{-1}$ of $\mathrm{CaCO}_{3}$.

The substrates were placed in handmade transparent plastic pots having a depth of 28 $\mathrm{cm}$, which was $3 \mathrm{~cm}$ more than the minimal requirements for shrub planting on intensive roof gardens (FLL, 1995). The pots were flexible so that their diameter could increase from 20 to $50 \mathrm{~cm}$ as soon as the plant roots appeared on the transparent pot wall. In this way the pot would not hinder the sideways movement of the roots. The initial diameter of the pots was $20 \mathrm{~cm}$ and the increase in pot diameter was achieved by four increments of $10 \mathrm{~cm}(20,30$, 40 , and $50 \mathrm{~cm}$ ) during the study. A nontransparent plastic liner was placed on the outer surface of the pots in order to exclude light.

The pots were placed on benches that permitted free drainage from the entire surface of the pot base, simulating the function of a roof garden drainage layer. The pots were hand irrigated until drainage at time intervals that were determined by the climatic conditions. Foliar fertilizer(Nutrileaf60; Miller, Hanover, $\mathrm{Pa}$.) was applied in weekly intervals during the first 2 months of the study and once every 2 months thereafter at the rate of $3 \mathrm{~g} \cdot \mathrm{L}^{-1}$. Granular fertilizer (Complesal, 6.3N-5.2P-14.1K1.2Mg-8S; AgrEvo Hellas S.A., Athens) was also applied in Jan., May, and Sept. 2001 at a rate of 22,25 , and $27 \mathrm{~g} /$ pot, respectively.

The study consisted of 60 plants, and plant growth rate measurements included shoot length, shoot number, bud and flower number, and diameter of the main shoot. A completely randomized design was used and analysis of variance was performed using JMP (SAS Inst., Cary, N.C.) statistical software and treatment means were compared using Tukey-Kramer HSD at a probability level $P \leq 0.05$. Mean air temperature (Fig. 1) and precipitation (Fig. 2) were recorded by the Laboratory of General and Agricultural Meteorology of the Agricultural Univ. of Athens.

In order to define the properties and suitability of each substrate for roof garden construction, the weight of each substrate was determined at saturation and at field capacity. For weight determination each substrate was packed in three PVC cylinders with 75-mm diameter and $28 \mathrm{~cm}$ high. To ensure uniform packing, a 20-cm-long extension was attached to the top of each cylinder. The cylinder with the attached extension was filled with the substrate and compaction was achieved by dropping 20 times a weight of $2 \mathrm{~kg}$ from a height of $20 \mathrm{~cm}$. The extension was then removed and the cylinders were slowly saturated from the base. After the determination of the saturated weight, the cylinders were left to drain freely for $24 \mathrm{~h}$ and were weighed again in order to determine their weight at field capacity. The substrates were

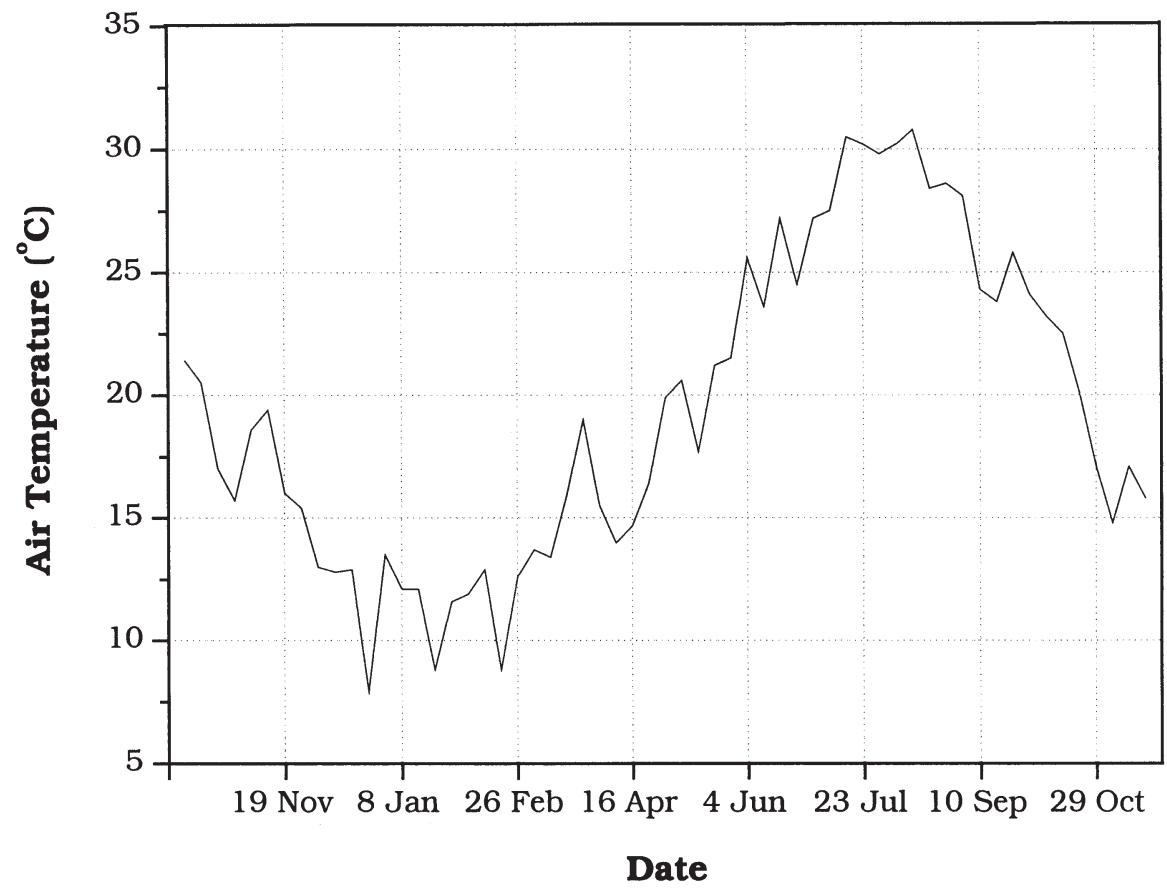

Fig. 1. Weekly mean air temperature $\left({ }^{\circ} \mathrm{C}\right)$ for the study period.

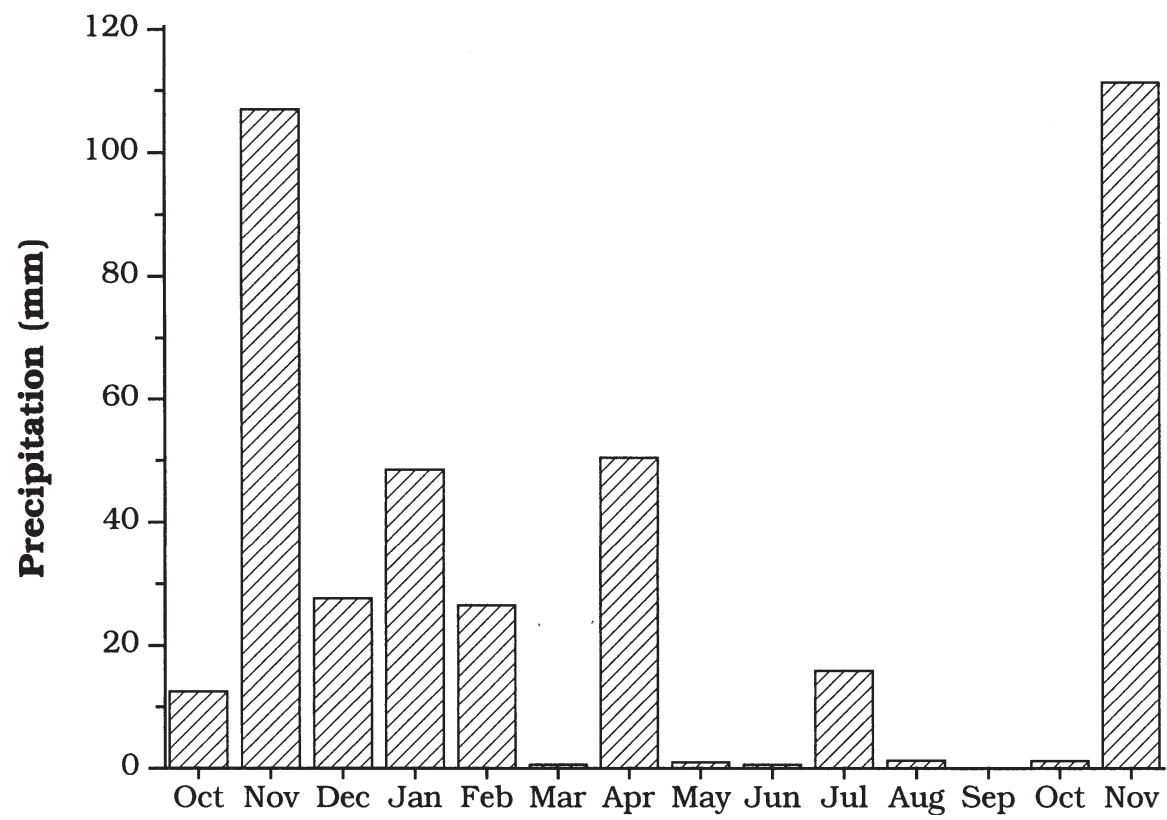

Fig. 2. Precipitation (mm) for the study period.

then removed from the cylinders and placed in a drying chamber at $105^{\circ} \mathrm{C}$ for $48 \mathrm{~h}$ for dry weight determination. For each substrate, a soil characteristic curve was determined using Richards's apparatus (Richards, 1949) with three replications per substrate. Bulk density, air-filled porosity at $40 \mathrm{~cm}, \mathrm{EC}$, and the $\mathrm{pH}$ at the initiation and termination of the study were also determined for each substrate.

\section{Results and Discussion}

Substrate characterization. Weight differences between the four different substrates are shown in Table 1 . The saturated weight of $S: F$,
S:P:Per and P:F was 14.8\%, 19.7\%, and 55.9\% less than that of the sandy loam substrate (S). At field capacity, the reduction in weight was $16.8 \%, 23.9 \%$, and $70.3 \%$ for S:F, S:P:Per, and P:F, respectively.

The reduction in weight at saturation and field capacity for substrates S:F and S:P:Per is limited and could not be considered as a clear advantage of these substrates compared to the sandy loam soil (S), even though differences were statistically significant. Conversely, the combination of peat and urea formaldehyde resin foam caused a significant weight reduction compared to the sandy loam soil, especially at field capacity (Table 1). 
Table 1. Physical and chemical properties of the substrates: 1) 100\% sandy loam soil (S); 2) sandy loam soil amended with urea-formaldehyde resin foam (S:F) at a proportion of 60:40 (v/v);3) sandy loam soil mixed with peat and perlite (S:P:Per) at a proportion of 50:30:20 (v/v); and 4) peat amended with a ureaformaldehyde resin foam (P:F) at a proportion of 60:40 (v/v). Values are the means of three replications. Means that differ significantly using Tukey-Kramer (HSD) at a probability level $P \leq 0.05$ are noted with different letters.

\begin{tabular}{|c|c|c|c|c|c|c|c|c|c|c|}
\hline \multirow[b]{2}{*}{ Substrate } & \multirow{2}{*}{$\begin{array}{c}\text { Wt at } \\
\text { saturation } \\
\left(\mathrm{kg} \cdot \mathrm{m}^{-3}\right)\end{array}$} & \multirow{2}{*}{$\begin{array}{c}\text { Wt at } \\
\text { field capacity } \\
\left(\mathrm{kg} \cdot \mathrm{m}^{-3}\right)\end{array}$} & \multirow{2}{*}{$\begin{array}{c}\text { Bulk } \\
\text { density } \\
\left(\mathrm{kg} \cdot \mathrm{m}^{-3}\right)\end{array}$} & \multirow{2}{*}{$\begin{array}{c}\text { Easily } \\
\text { available water } \\
(\% \mathrm{v} / \mathrm{v})\end{array}$} & \multirow{2}{*}{$\begin{array}{l}\text { Total } \\
\text { porosity } \\
(\%)\end{array}$} & \multirow{2}{*}{$\begin{array}{c}\text { Air-filled porosity } \\
\text { at } 40 \mathrm{~cm} \\
(\% \mathrm{v} / \mathrm{v})\end{array}$} & \multicolumn{2}{|c|}{$\mathrm{pH}^{\mathrm{z}}$} & \multicolumn{2}{|c|}{$\mathrm{EC}\left(\mathrm{dS} \cdot \mathrm{m}^{-1}\right)$} \\
\hline & & & & & & & Initial & Final & Initial & Final \\
\hline $\mathrm{S}$ & $1758.9 \mathrm{a}$ & $1657.8 \mathrm{a}$ & $1511.7 \mathrm{a}$ & $10.6 \mathrm{~b}$ & $45.9 \mathrm{c}$ & $21.9 \mathrm{c}$ & $7.25 \mathrm{a}$ & $8.61 \mathrm{a}$ & $1.60 \mathrm{~b}$ & $1.00 \mathrm{c}$ \\
\hline $\mathrm{S}: \mathrm{F}$ & $1497.8 \mathrm{~b}$ & $1379.3 \mathrm{~b}$ & $811.4 \mathrm{~b}$ & $10.2 \mathrm{~b}$ & $45.3 \mathrm{c}$ & $23.6 \mathrm{bc}$ & $6.84 \mathrm{a}$ & $8.29 \mathrm{ab}$ & $2.10 \mathrm{a}$ & $3.00 \mathrm{~b}$ \\
\hline S:P:Per & $1411.4 \mathrm{~b}$ & $1261.4 \mathrm{~b}$ & $854.2 \mathrm{~b}$ & $11.8 \mathrm{~b}$ & $57.4 \mathrm{~b}$ & $25.7 \mathrm{~b}$ & $6.62 \mathrm{a}$ & $8.12 \mathrm{~b}$ & $1.38 \mathrm{~b}$ & $1.22 \mathrm{c}$ \\
\hline P:F & $776.1 \mathrm{c}$ & $491.4 \mathrm{c}$ & $68.2 \mathrm{c}$ & $26.0 \mathrm{a}$ & $86.0 \mathrm{a}$ & $49.0 \mathrm{a}$ & $6.42 \mathrm{a}^{\mathrm{y}}$ & $7.99 \mathrm{~b}$ & $2.18 \mathrm{a}$ & $6.22 \mathrm{a}$ \\
\hline
\end{tabular}

${ }^{2} \mathrm{pH}$ measurements were performed in 1:1 w/w saturated paste for substrates S, S:F and S:P:Per and in 1:1 v/v saturated paste for substrate P:F.

${ }^{y}$ The initial $\mathrm{pH}$ of substrate $\mathrm{P}: \mathrm{F}$ was 3.15 and therefore it was corrected with the addition of $22 \mathrm{~g} \cdot \mathrm{L}^{-1}$ of $\mathrm{CaCO}_{3}$.

The addition of peat/perlite and urea formaldehyde resin foam reduced the bulk density of the substrate by $43 \%$ and $46 \%$, respectively. However, the reduction in substrate weight was minimal due to the capacity of the resin foam and peat/perlite to absorb significant amounts of water $(60 \%$ to $70 \%, \mathrm{v} / \mathrm{v})$.

From the water release curves of each substrate (Fig. 3), it is apparent that the resin foam amendment $(\mathrm{S}: \mathrm{F})$, when compared to substrate $\mathrm{S}$, did not alter the water release pattern even though bulk density was significantly reduced. This implies that the pore size distribution within the resin foam closely resembles the porosity architecture of the sandy loam soil. On the contrary, peat/perlite amendment increased the macroporosity of the substrate as indicated by the water release curve of substrate S:P:Per. Based on the above, the increased macroporosity observed in substrate $\mathrm{P}: \mathrm{F}$ is due to the peat rather than the resin foam amendment. Easily available water (EAW) had similar values for substrates $S, S: F$, and S:P:Per while substrate P:F exhibited a 2.5 times higher EAW value (Table 1).

The $\mathrm{pH}$ slightly increased during the study exhibiting a similar pattern for all substrates (Table 1). In contrast, initial and final EC values were different for the four substrates. The initial EC of the substrates containing resin foam was increased due to the EC of the resin foam $\left(8.5 \mathrm{dS} \cdot \mathrm{m}^{-1}\right)$. However, the differential response of substrates $\mathrm{S}: \mathrm{F}$ and $\mathrm{P}: \mathrm{F}$ between initial and final $\mathrm{EC}$ values reflects differences in leaching pattern between the substrates (Table 1). The reduction of EC from the initiation to the termination of the study for substrates $\mathrm{S}$ and $\mathrm{S}: \mathrm{P}:$ Per is understandable since there were several rainfall events on Nov. 2001, resulting in leaching of salts (Fig. 2). On the contrary, the high EC value at the termination of the study in substrate P:F reveals that the high water-holding capacity of this substrate did not permit fast leaching, thus resulting in salt accumulation. In addition, since EC increased in both resin-foam containing substrates ( $\mathrm{S}: \mathrm{F}$ and $\mathrm{P}: \mathrm{F}$ ) it is possible that resin foam entraps soil solution within its pores resulting in salt accumulation.

Shoot length. In the early stage of the study, differences between the four substrates were not evident due to the reduced growth of $L$. camara in autumn and winter (Figs. 1 and 4 ). Differences in shoot length appeared in late winter, about $175 \mathrm{~d}$ after the initiation of the study, with substrates $\mathrm{S}$ and S:F producing

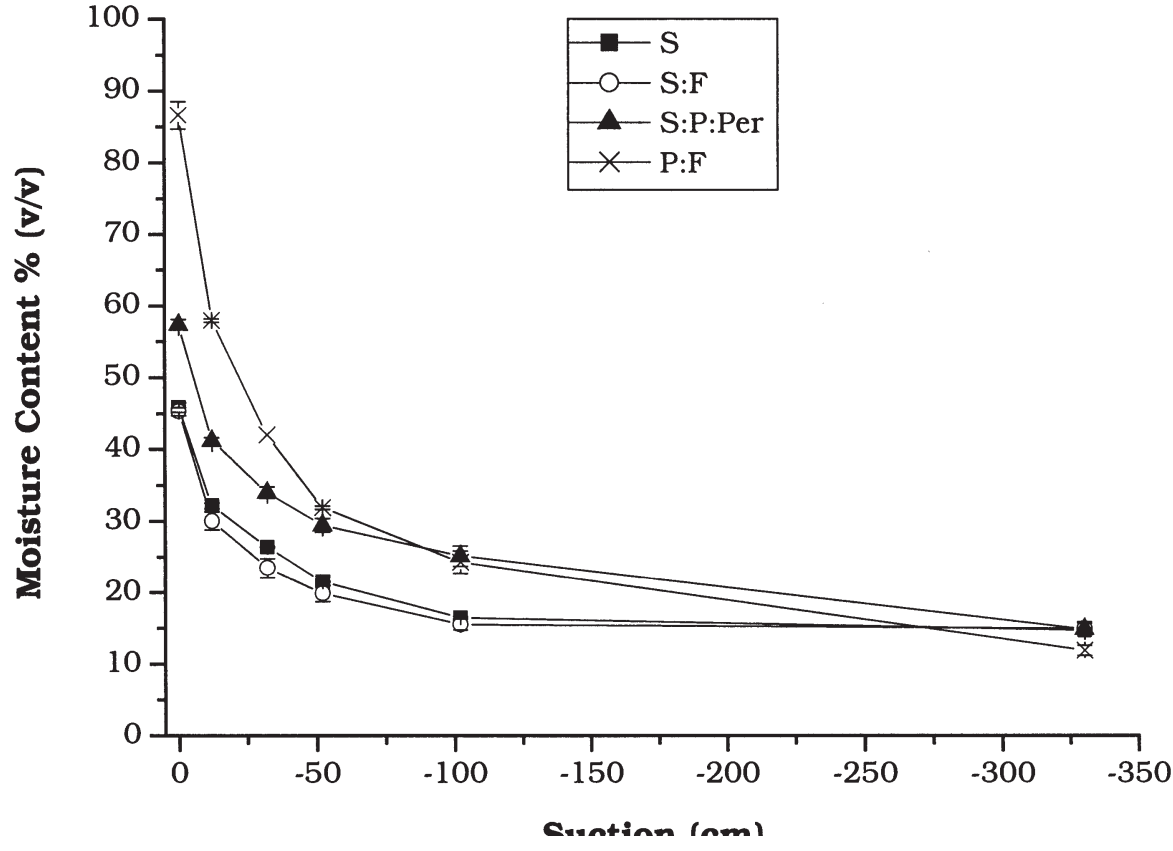

Fig. 3. Water release curves for: a) 100\% sandy loam soil (S); b) sandy loam soil amended with urea-formaldehyde resin foam (S:F) at a proportion of 60:40 (v/v); c) sandy loam soil mixed with peat and perlite (S:P:Per) at a proportion of 50:30:20 (v/v); and d) peat amended with a urea-formaldehyde resin foam $(\mathrm{P}: \mathrm{F})$ at a proportion of $60: 40(\mathrm{v} / \mathrm{v})$. Values are means of three replications. Bars represent \pm SE.

longer shoots and a faster shoot elongation rate compared to substrates P:F and S:P:Per. This pattern continued until April, when the shoot growth of plants in substrate S:P:Per, which had initially lagged, increased and shoot length reached an average length of $36 \mathrm{~cm}$, which was similar to the $38 \mathrm{~cm}$ of the control substrate S (Fig. 4).

The slow initial shoot elongation rate of plants in substrates S:P:Per and P:F compared to the substrates $\mathrm{S}$ and $\mathrm{S}: \mathrm{F}$ appears to relate to the increased water holding capacity of the former (Fig. 3), which resulted in a waterlogging stress during winter when evapotranspiration demands were low. This is substantiated by the abrupt shoot length increase in substrate $\mathrm{S}: \mathrm{P}:$ Per in late spring when evapotranspiration increases.

After the sixth sampling date shoot elongation in substrate P:F was significantly less compared to all the other substrates (Fig. 4). This growth reduction is attributed to the increased EC values observed in P:F substrate (Francois and Clark, 1978; Wilkinson, 1994) along with the high moisture content of the substrate. As a result of the high EC values, substrate P:
F exhibited chlorosis and nutrient deficiency symptoms (Lea-Cox and Syvertsen, 1993) that were evident despite the frequent fertilizer applications and which were exacerbated by the waterlogging conditions. In addition, the final diameter of the main (Table 2) and the lateral shoots in P:F substrate was smaller compared to all the other substrates.

Lateral shoot number. Plants in substrates $\mathrm{S}$ exhibited a higher production of lateral shoots compared to substrate P:F at the first and third sampling date while substrate S:F produced more lateral shoots compared to substrate P:Fat the third sampling date (Fig. 5). Subsequently, the number of lateral shoots of substrate P:F increased substantially, indicating the existence of a mechanism that provoked prolific lateral shoot production.

Since substrate P:F was characterized by increased water-holding capacity (Fig. 3) a possible mechanism for the lateral shoot number increase might be ethylene production, which is known to occur under waterlogging conditions (Bradford and Yang, 1980). Elevated ethylene levels can cause shoot primordial formation as well as lateral bud development (Grichko 


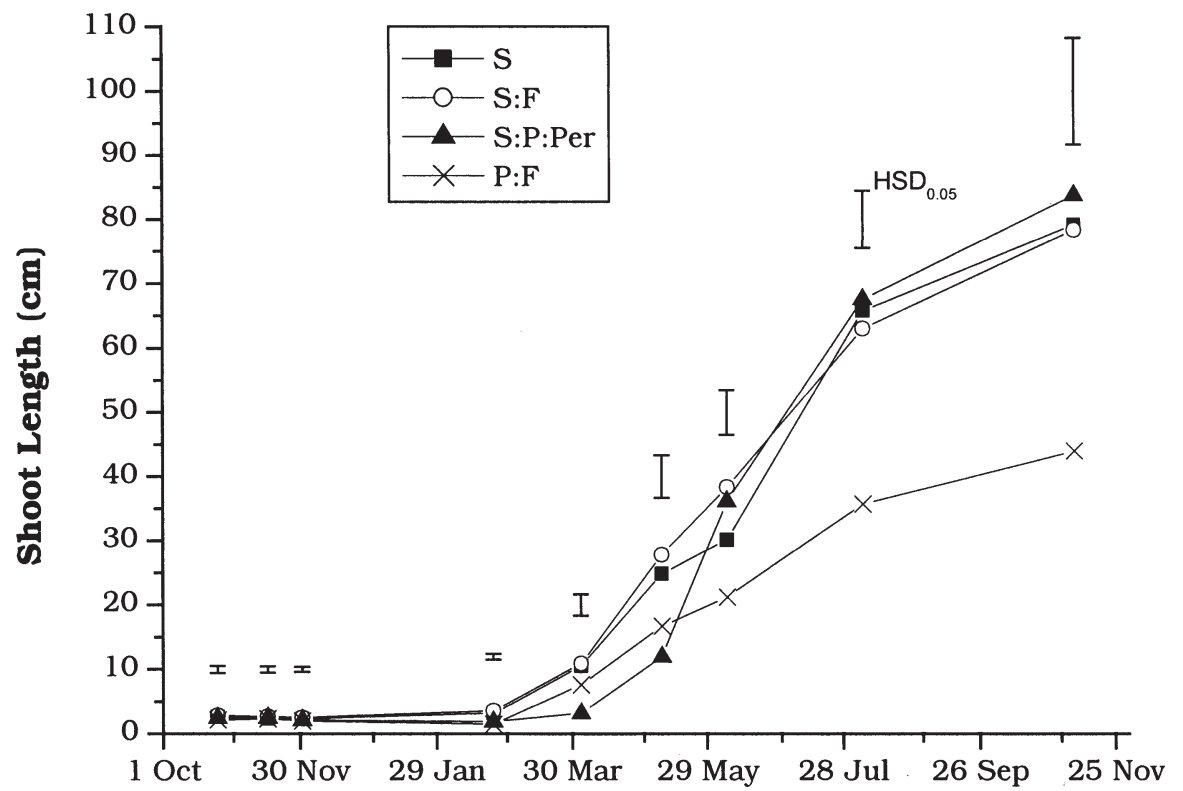

Date

Fig. 4. Shoot length of L. camara as affected by substrates: a) $100 \%$ sandy loam soil (S); b) sandy loam soil amended with urea-formaldehyde resin foam (S:F) at a proportion of 60:40 (v/v); c) sandy loam soil mixed with peat and perlite (S:P:Per) at a proportion of 50:30:20 (v/v); and d) peat amended with a urea-formaldehyde resin foam (P:F) at a proportion of 60:40 (v/v). Values are the means of 15 replications. Bars represents Tukey-Kramer's (HSD) at $P \leq 0.05$.

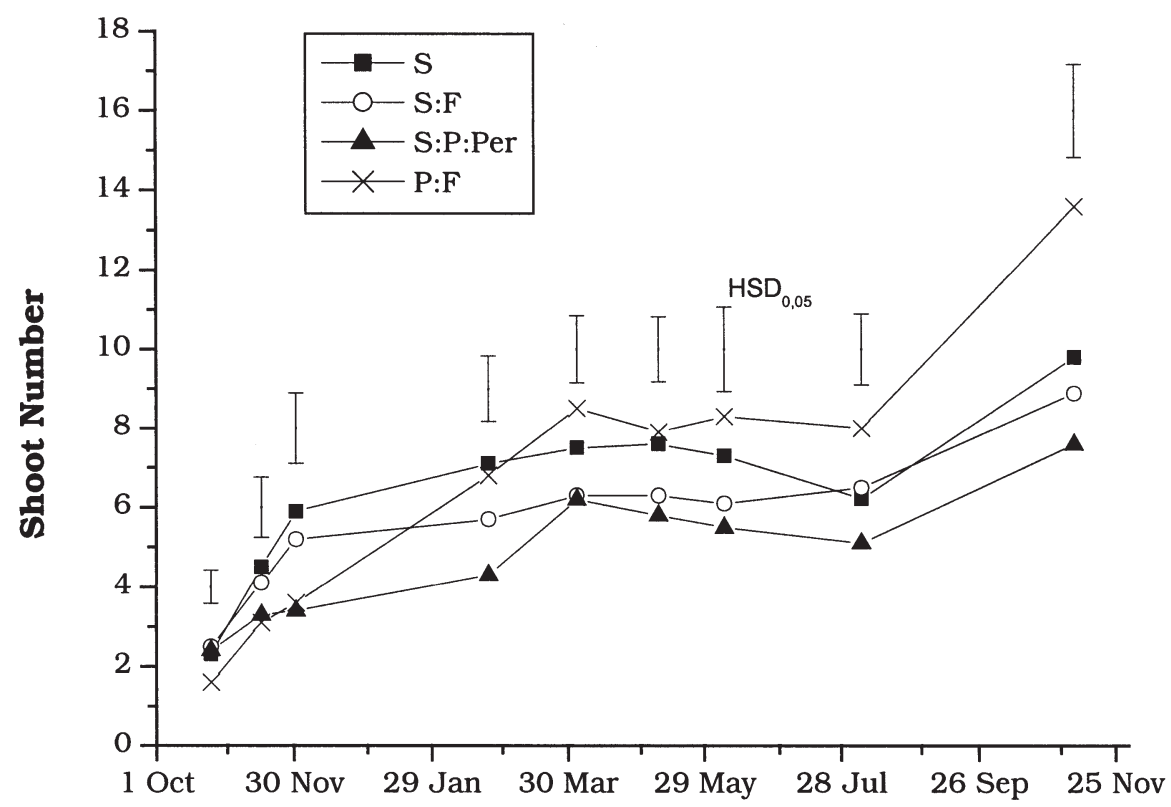

Date

Fig. 5. Shoot number of L. camara as affected by substrates: a) $100 \%$ sandy loam soil (S); b) sandy loam soil amended with urea-formaldehyde resin foam (S:F) at a proportion of 60:40 (v/v); c) sandy loam soil mixed with peat and perlite (S:P:Per) at a proportion of 50:30:20 (v/v); and d) peat amended with a urea-formaldehyde resin foam (P:F) at a proportion of 60:40 (v/v). Values are the means of 15 replications. Bars represent Tukey-Kramer's (HSD) at $P \leq 0.05$.

and Glick, 2001). However, epinasty, which is usually detectable under anaerobic conditions, was not evident in substrate P:F. Additionally, substrate S:P:Per, which also had a high waterretention capacity under low suction values (Fig. 3), did not exhibit prolific lateral shoot production. Therefore, it is speculated that the prolific lateral shoot production was a reac-
Table 2. Flower bud number, cumulative flower number, and main shoot diameter of L. camara as affected by substrates: 1) $100 \%$ sandy loam soil (S); 2) sandy loam soil amended with ureaformaldehyde resin foam (S:F) at a proportion of $60: 40(\mathrm{v} / \mathrm{v}) ; 3)$ sandy loam soil mixed with peat and perlite (S:P:Per) at a proportion of 50: $30: 20(\mathrm{v} / \mathrm{v})$; and 4) peat amended with a ureaformaldehyde resin foam (P:F) at a proportion of $60: 40(\mathrm{v} / \mathrm{v})$. Values are the means of 15 replications. Means that differ significantly using Tukey-Kramer (HSD) at a probability level $P \leq$ 0.05 are noted with different letters.

\begin{tabular}{|c|c|c|c|}
\hline Substrate & $\begin{array}{l}\text { Flower } \\
\text { bud no. }\end{array}$ & $\begin{array}{l}\text { Cumulative } \\
\text { flower no. }\end{array}$ & $\begin{array}{l}\text { Main shoot } \\
\text { diam }(\mathrm{mm})\end{array}$ \\
\hline \multicolumn{4}{|c|}{3 Apr. 2001} \\
\hline S & $11.5 \mathrm{a}$ & 0.0 & $--^{z}$ \\
\hline$S: F$ & $12.0 \mathrm{a}$ & 0.0 & --- \\
\hline S:P:Per & $0.0 \mathrm{~b}$ & 0.0 & --- \\
\hline$P: F$ & $2.2 \mathrm{~b}$ & 0.0 & --- \\
\hline $\mathrm{HSD}_{0.05}$ & 8.46 & --- & --- \\
\hline \multicolumn{4}{|c|}{9 May 2001} \\
\hline S & $55.8 \mathrm{~b}$ & $28.8 \mathrm{a}$ & $7.0 \mathrm{a}$ \\
\hline$S: F$ & $92.1 \mathrm{a}$ & $29.6 \mathrm{a}$ & $7.8 \mathrm{a}$ \\
\hline S:P:Per & $8.1 \mathrm{c}$ & $0.1 \mathrm{~b}$ & $5.7 \mathrm{~b}$ \\
\hline$P: F$ & $30.8 \mathrm{bc}$ & $9.7 \mathrm{~b}$ & $5.3 \mathrm{~b}$ \\
\hline $\mathrm{HSD}_{0.05}$ & 25.77 & 15.53 & 1.27 \\
\hline \multicolumn{4}{|c|}{7 June 2001} \\
\hline $\mathrm{S}$ & $54.9 \mathrm{~b}$ & $89.3 \mathrm{~b}$ & $9.9 \mathrm{a}$ \\
\hline$S: F$ & $95.3 \mathrm{a}$ & $150.4 \mathrm{a}$ & $9.5 \mathrm{a}$ \\
\hline S:P:Per & $88.9 \mathrm{a}$ & $28.5 \mathrm{c}$ & $7.2 \mathrm{~b}$ \\
\hline$P: F$ & $40.6 \mathrm{~b}$ & $20.8 \mathrm{c}$ & $5.4 \mathrm{c}$ \\
\hline $\mathrm{HSD}_{0.05}$ & 26.03 & 30.81 & 1.50 \\
\hline \multicolumn{4}{|c|}{6 Aug. 2001} \\
\hline S & $58.2 \mathrm{ab}$ & $150.8 \mathrm{~b}$ & $--^{2}$ \\
\hline $\mathrm{S}: \mathrm{F}$ & $65.3 \mathrm{a}$ & 235.9 a & --- \\
\hline S:P:Per & $60.3 \mathrm{a}$ & $100.0 \mathrm{c}$ & --- \\
\hline$P: F$ & $32.9 \mathrm{~b}$ & $70.0 \mathrm{c}$ & --- \\
\hline $\mathrm{HSD}_{0.05}$ & 27.69 & 48.83 & \\
\hline \multicolumn{4}{|c|}{7 Nov. 2001} \\
\hline S & $18.6 \mathrm{a}$ & $261.0 \mathrm{ab}$ & $20.7 \mathrm{a}$ \\
\hline$S: F$ & $15.1 \mathrm{a}$ & $321.8 \mathrm{a}$ & $19.2 \mathrm{a}$ \\
\hline S:P:Per & $19.4 \mathrm{a}$ & $219.4 \mathrm{~b}$ & $19.0 \mathrm{a}$ \\
\hline$P: F$ & $1.6 \mathrm{~b}$ & $141.2 \mathrm{c}$ & $14.7 \mathrm{~b}$ \\
\hline $\mathrm{HSD}_{005}$ & 5.87 & 69.27 & 2.81 \\
\hline
\end{tabular}

${ }^{\mathrm{z}}$ Measurements were not taken.

After June the rate of flower production was similar for substrates $S$ and $S: F$, while substrate S:P:Per exhibited an increased flower production rate in August and November. Substrate P:F produced the least number of buds and flowers, a significant number of which aborted before blooming, indicating that the nutritional status of the plants could not support flower growth. It is noticeable that, flower production closely resembled the shoot elongation rate, which seems to be an explanation for the observed differences in flowering between the four substrates since L camara produces its flowers at the distal end of the shoots (Pizzetti and Cocker, 1975).

The best plant growth response was achieved in substrates $S$ and S:F. However, although $\mathrm{S}$ is considered to be a good growing medium, its increased bulk density limits its use as roof garden plant substrate. The amendment of soil with the resin foam improved the growth and flowering of L. camara, while at the same time reduced the weight of the substrate by $\approx 17 \%$ at field capacity, providing a significant saving to the buildings' construction cost. The 
peat/perlite amendment exhibited a differential response that was related to the climatic conditions. The slow initial shoot growth during the establishment period while the root system was not fully developed can be considered as an advantage in windy areas, due to the reduced torque that is applied to the plants by the wind. However, peat/perlite amendment has the capacity to support the same plant growth as the abovementioned substrates, while at the same time it has a slightly better weight reduction compared to substrate S:F, reaching $24 \%$ at field capacity. The amendment of peat with the resin foam provided a lightweight substrate. However, due to the high maintenance requirements, the reduced support of plant growth and the increased EC, its use should be considered only in special cases where reduced weight of the roof garden is imperative.

\section{Literature Cited}

Boivin, M.A., M.P. Lamy, A. Gosselin, and B. Dansereau. 2001. Effect of artificial substrate depth on freezing injury of six herbaceous perennials grown in a green roof system. HortTechnology
11(3):409-412.

Bradford, K.J. and S.F. Yang. 1980. Xylem transport of 1-aminocyclopropane-1-carboxylic acid, and ethylene precursor, in waterlogged tomato plants. Plant Physiol. 65:322-326.

Bunt, A.C. 1988. Media and mixes for containergrown plants. Unwin Hyman, London, U.K.

Fisher, P. and M. Jauch. 1995. Substrate für einschichtige Dachbegrünung-Zweijährige Versuchsergebnisse. Dach und Grün 3:542-546.

Forschungsgesellschaft Landschaftsentwicklung Landschaftsbau e.V. (FLL). 1995. Richtlinien für die Planung, Ausführung und Pflege von Dachbegrünungen. Richtlinien für Dachbegrünungen (Guidelines for the planning, execution and upkeep of green-roof sites). Selbstverlag, Troisdorf.

Francois, L.E. and R.A. Clark. 1978. Salt tolerance of ornamental shrubs, trees and Iceplant. J. Amer. Soc. Hort. Sci. 103:280-283.

Grichko, V.P. and B.R. Glick. 2001. Ethylene and flooding stress in plants. Plant Physiol. Biochem. 39:1-9.

Kulshreshtha, K., A. Farooqui, K. Srivastava, S.N. Singh, K.J. Ahmad, and H.M. Behl. 1994. Effect of diesel exhaust pollution on cuticular and epidermal features of Lantana camara L. and Syzygium cuminii L. (Skeels.). J. Environ. Sci.
Health A29(2):301-308.

Lea-Cox, J.D. and J.P. Syvertsen. 1993. Salinity reduces water use and nitrate-N-use efficiency of citrus. Ann. Bot. 72:47-54

Liesecke, H. 1998. Das Retentionsvermögen von Dachbegrünungen. Stadt und Grün. 47:46-53.

Onmura, S., M. Matsumoto, and S. Hokoi. 2001. Study on the evaporative cooling effect of roof lawn gardens. Energy and Buildings. 33: 653-666.

Osmundson, T. 1999. Roof gardens: History, design, and construction. Norton, New York.

Pizzetti, I. and H. Cocker. 1975. Flowers: A guide for your garden. Abrams, New York.

Richards, L.A. 1949. Methods of measuring soil moisture tension. Soil Sci. 68:95-112.

Schade, C. 2000. Wasserrückhaltung und Abflußwerte bei dünnschichtigen Extensivbegrünungen. Stadt und Grün. 2:95-100.

Scholz-Barth, K. 2001. Green roofs: Stormwater management from the top down. Environ. Design and Construction. Jan./Feb.

Scrivens, S. 1990. Urban landscape and roof gardens, p. 131-151. In: B. Clouston (ed). Landscape design with plants, 2nd ed. Butterworth-Heinemann, Oxford, U.K.

Wilkinson, R.E. 1994. Plant-environment interactions. Marcel Dekker, New York. 